\title{
Analysis on Social Responsibility Report of Metallurgical Industry in
}

\author{
China \\ Sun Yun ${ }^{1, a^{*}}$, Pan Zheyu ${ }^{2, b^{*}}$, Zhi Ruowen ${ }^{3, c^{*}}$ \\ ${ }^{1}$ North China Electric Power University, Beijing, china \\ ${ }^{2}$ North China Electric Power University, Beijing, china \\ ${ }^{3}$ North China Electric Power University, Beijing, china \\ amosusu1026@163.com, b1145966838@qq.com, cer11511@126.com
}

Keywords: Metallurgical Industry; Steel Industry ; Social Responsibility
Report ;Problem ;Suggestions

\begin{abstract}
With the proposed concept of sustainable development, an increasing number of Chinese enterprises began to pay attention to corporate social responsibility and the preparation of reports. Corporate social responsibility report is an important carrier of non-financial information disclosure, is the enterprise important bridge of communication with stakeholders. Not only is the metallurgical industry an important raw materials industrial sector, providing metal materials for national economy departments and material basis of economy development, but also a heavy polluting industry. Metallurgical enterprises have reached some progress in their social responsibility report in 6 years of development. Nevertheless, there are still some shortcomings which limited the development of metallurgical industry in social responsibility reports essentially. This paper analyzes on the existing problems and gives related suggestions according to the present situation of social responsibility reports of metallurgical industry in China, the present situation and problems of present metallurgy industry social responsibility report analysis. Finally, puts forward some solutions.
\end{abstract}

\section{Introduction}

Metallurgical industry refers to metallic mineral exploration, mining, selection, smelting and rolling timber industry, including ferrous metallurgical industry(steel industry) and non-ferrous metallurgical industry. On one hand, metallurgical industry in China has achieved great progress, on the other, there are still problems existing needed to be solved when facing the challenging of economic globalization and sustainable development. This paper is based on the 164 social responsibility report issued from 2008 to 2013 the metallurgical industry, analysis on the existing problems.

\section{Development of Metallurgical industry in China and its social responsibility report}

Development of Metallurgical industry in China. Metallurgical industry has developed rapidly for more than 60 years after the founding of New China. Entering the 21st century, steel remains to be human being's raw metal which cannot be replaced, as well as an important index measuring the comprehensive power and industry level of a country. 
As of 2012, the total production of steel industry has been the first place for 9 years continuously, as well as the consuming country and producing country of non-ferrous metal. However, the further development of metallurgical industry brings the side effects in varying degrees, including the waste of resource, environmental pollution and the frequent safety accidents and so on. Therefore, how can the metallurgical industry development in a sustainable way will be the point for new metallurgical enterprises.

Development of its social responsibility report. A total of 23 iron and steel enterprises in 2013, 11 non-ferrous metal corporate social responsibility report issued or sustainable development report. We collected from 2008 to 2013, 56 steel industry listed companies and 49 nonferrous metal industry listed companies issued by 164 social responsibility report. On the whole, release social responsibility report companies continue to grow, length increasing, the content is more abundant. As can be seen in metallurgical enterprise in the process of writing reports every year, gradually find the right writing basis, began to think about their own social and cultural ideas, exploration and attempt to disclose the key data and negative information, corporate social responsibility management level improved significantly. At the same time, the problem still remaining.

\section{The problem of the steel industry listed company social responsibility report}

Less disclosure of content and multiform. Corporate social responsibility report forms for metallurgy industry is relatively single. Mainly text versions of metallurgy industry enterprises, the use of no more vivid illustrations, photographs, reflects the fact that most companies have not realize the importance of social responsibility report, just go with the flow or forced to write. Illustrated reports can more comprehensive response of social responsibility content, forms of diversity also increases the readability of the report, color is rich vivid, explanatory power enhancement also make readers easier to read. Only text version of the social responsibility report reading is difficult, to the general reader lose interest in reading, perfunctory feeling strong, reflect information incomplete, it is difficult to achieve social responsibility report due utility.

Table 1 Statistics on pages of social responsibility report of steel enterprises

\begin{tabular}{|l|l|l|}
\hline Average pages & Enterprises & Percentage \\
\hline Fewer than 20 & 33 & $81 \%$ \\
\hline 20 to 50 & 5 & $12 \%$ \\
\hline More than 50 & 3 & $7 \%$ \\
\hline
\end{tabular}

Data Source: Social responsibility report of metallurgical industry listed companies in 2008 to 2013

Inconsistent standards of report writing. Inconsistent standards of report writing in enterprises of metallurgical industry will cause the problem of lack of standardization, the loss of content, incapability of comparison and so on. And a company usually reference guide to write the report more, more let the reader no comparison. 
Table 2 Iron and steel industry social responsibility report preparation standard

\begin{tabular}{|l|l|l|}
\hline Standard & Enterprises & Percentage \\
\hline Lack of standardization & 16 & $39 \%$ \\
\hline $\begin{array}{l}\text { 'Shenzhen stock exchange listed company social } \\
\text { responsibility guidelines' or 'environmental information } \\
\text { disclosure of listed companies of Shanghai stock } \\
\text { exchange guidelines' and 'the Shenzhen stock exchange }\end{array}$ & $44 \%$ \\
\hline main board listed companies operating guidelines' & & \\
\hline $\begin{array}{l}\text { the global reporting initiative (GRI) guidelines for the } \\
\text { sustainable development report (G3) }\end{array}$ & 7 & $17 \%$ \\
\hline $\begin{array}{l}\text { the Chinese academy of social sciences in China } \\
\text { corporate social responsibility report writing guide } \\
\text { "(CASS - CSR 2.0) }\end{array}$ & 4 & $10 \%$ \\
\hline $\begin{array}{l}\text { the international organization for standardization ISO } \\
\text { 26000: social responsibility guidelines (2010) }\end{array}$ & 3 & $7 \%$ \\
\hline $\begin{array}{l}\text { the People's Republic of China on the guidance of the } \\
\text { central enterprises to fulfill social responsibility }\end{array}$ & 2 & $5 \%$ \\
\hline $\begin{array}{l}\text { China's industrial economy federation of Chinese } \\
\text { industrial enterprises and industrial association, social } \\
\text { responsibility guidelines (GSRI - CHINA 2.0) }\end{array}$ & 1 & $3 \%$ \\
\hline $\begin{array}{l}\text { the environmental information disclosure measures (try } \\
\text { out) and listed on further strict environmental protection } \\
\text { verification management system to strengthen the } \\
\text { environmental protection verification of listed companies } \\
\text { after the supervision work of the notice and the } \\
\text { environmental information disclosure of listed company } \\
\text { guidelines (draft) }\end{array}$ & 1 & \\
\hline
\end{tabular}

Data resource: Social responsibility report of metallurgical industry listed companies in 2008 to 2013

Non-third party inspection, poor reliability. None of the social responsibility report of metallurgical industry has the inspection of a third party, most of them only made the insurance in the beginning of the report. However, the social responsibility report in other industry, most of them gained a third party inspection even for many years. Visible to the third party inspection at this stage in our country social responsibility report the status and importance.

Compared to the electric power enterprises or other high score enterprises, there is still room for the social responsibility report of metallurgical industry for progress.

A lack of industry characteristics. According to Chinese nonferrous metal resources central south university and strategic research institute jointly issued the '2013 China metal social responsibility competitiveness report of listed companies and the Chinese academy of social sciences published by the China corporate social responsibility report (2013)', I picked on the social responsibility index and three steel metallurgy industry overall average is most close to Fujian light, as a representative of the general level of metallurgical industry, metallurgical industry and get the highest score of Baosteel steel are compared, at the same time, based on the metallurgical industry for 6 years. 
The content of the responsibility all in the same key. The social responsibility report written by steel industry consists of review, shareholders and the protection of the rights and interests of the debtor, the protection of the rights and interests of employees, suppliers, customers and consumers' rights and interests protection, environment protection and sustainable development, public relations and the social public welfare undertakings and other parts.

In the aspects of public relations and the social public welfare, a large number of enterprises did not show their characteristic social responsibility. For example in Baosteel steel report mentioned in their performance of the green manufacturing of Baosteel steel at the same time, do not forget to undertake the leader of national iron and steel industry energy conservation and environmental protection and international steel market competition the main body of history and social responsibility.

non-representative environmental index. In the aspect of social responsibility index, the disclose of the data should be representative. Baosteel disclosed the consumption of materials like iron ore, coal, water and electric power, the discharge value of the pollution like SO2, dust, COD and the factory atmosphere precipitation amount, Comprehensive utilization of secondary resources production and management in all four categories of 25 events, index content appropriate production feature of metallurgical industry. And San Steel Minguang only revealed six data also does not have in the past year. But on the whole, disclose the relevant data system adopted in 2013 form just eight of metallurgy industry enterprises, accounting for $20 \%$. More companies not to waste water exhaust to sum up, is to have meet the national discharge standard in a word, not only the content is not specific and how to process instead of the results, the use of low value for the reader.

\section{Solution for improve the social responsibility report level of steel industry}

Establishing related laws and regulations and mechanism. The Shanghai stock exchange since 2008, three types of listed companies have disclosed social responsibility report, including as a plate sample of 230 companies, corporate governance in listed abroad of 21,50 financial companies, these 258 listed companies, as well as other companies to disclose. In addition to the stock exchange shall continue to adopt measures to encourage with mandatory system, the legislation of our country administrative agencies also shall establish and improve the relevant laws and regulations in a timely manner to ensure the legal status of social responsibility report.

To strengthen the third party inspection and localization. The third party inspection can improve social responsibility report disclosed the objectivity and reliability of information, and it can improve the influence of the social responsibility report.

According to the third party inspection, at present, our country has not issued corporate social responsibility report of the third party inspection mandatory regulation. The government department, the ministry of commerce and industry shall be issued corresponding policies, actively promote social responsibility report the localization of the third party inspection institutions, may be extended appropriately foreign inspection institutions of business access in China, the social responsibility report shall be submitted at the same time vigorously develop professional and formulate a unified standard of review.

Relying on a uniform index, strengthening the industry characteristics. Industry index can be unified response to the industry characteristics, more targeted supervision enterprises to fulfill social responsibility, also is advantageous to the social responsibility report of transverse comparison. Therefore, our country should pay attention to strengthen trade organizations in the role. 


\section{Summary}

At this point, we analyzed the problems existing in the metallurgical industry, social responsibility report, and puts forward some solutions. Believe that along with the further strengthening of economic globalization and the further development of the economy in our country, the social responsibility report will occupy more important position, also sincerely hope that our country's social responsibility report quality can make great progress.

\section{References}

[1]Chen Honghui Zhanglin third party review: Magazine the judge of social responsibility board of directors 2013,7

[2]China textile industry association to launch social responsibility report people's daily $02 / 12 / 2007$

[3]The status of China's steel industry analysis and the breakthrough. The northeast news

[4]Corporate social responsibility analysis in yunnan metallurgical group co., LTD., for example The king to learn Yunnan university master's degree thesis

[5]2013 China metal social responsibility competitiveness report of listed companies of China nonferrous metals Central south university metal resources strategic research institute

[6]Corporate social responsibility communication of Chinese and global corporations in China. Lu Tanga, Hongmei Li ,2009/05

[7]Determinants of sustainability reporting: a review of results, trends,

theory, and opportunities in an expanding field of research Rüdiger Hahn, Michael Kühnen ,2013/07

[8]The absence of corporate social responsibility reporting in Bangladesh Ataur Rahman Belal, Stuart Cooper,2010/06

[9]CSR2013 baosteel,2013

[10]CSR2013 wusteel,2013 